\title{
ON THE MOdern CNC MiLling WiTH A COMPENSATION OF CUTTING TOOLS DEFLECTIONS
}

\author{
POLZER, A.; PisKa, M. \& DUFKOVA, K.
}

Abstract: Accuracy of machined components is one of the most critical considerations for any manufacturer. However, when milling the radial force deflects the cutting tool and it affects the precision and quality of machined surfaces. The extent of the deviations can be predicted in various mathematical models. Thus, the errors can be compensated in NC programme effectively. So it is possible to machine with high cutting conditions, and also a high quality of machined surface can be achieved. In this paper are presented mathematics models for prediction deflection of milling tools with two and four flutes. The experimental results show that the overall error in the flexible milling can be captured and predicted with very high accuracy.

Key words: CNC, Milling, Prediction, Deflection, Compensation
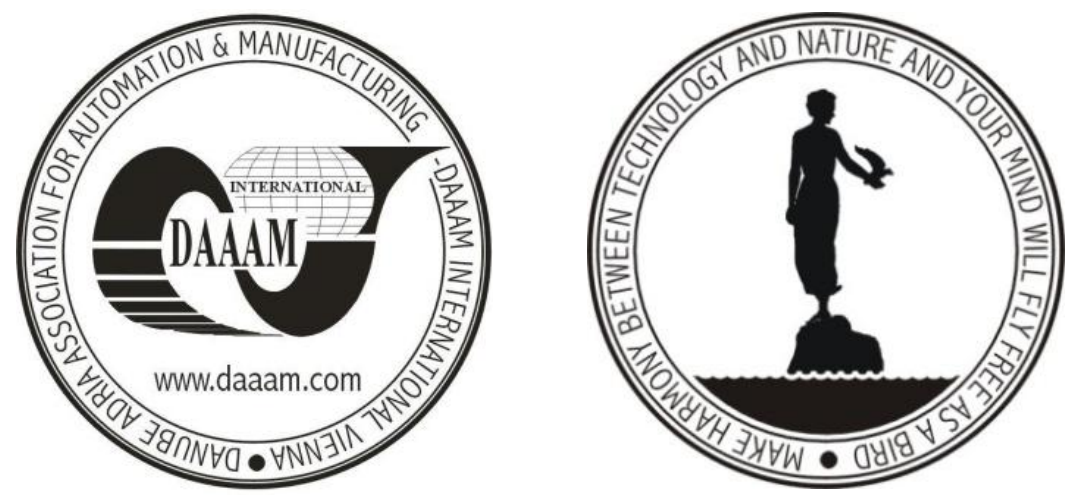

Authors' data: Dipl.-Ing. Ph.D. Polzer, A[les]*; Prof. Dipl.-Ing. CSc. Piska, M[iroslav]*, Dipl.-Ing. Dufkova, K[aterina]*, *Brno University of Technology, Technicka 2896/2, 616 69, Brno, Czech Republic, polzer@fme.vutbr.cz, piska@fme.vutbr.cz,dufkova@fme.vutbr.cz

This Publication has to be referred as: Polzer, A[les]; Piska, M[iroslav] \& Dufkova, K[aterina] (2014). On the Modern Cnc Milling With a Compensation of Cutting Tools Deflections, Chapter 25 in DAAAM International Scientific Book 2014, pp.311-322, B. Katalinic (Ed.), Published by DAAAM International, ISBN 978-3-901509-98-8, ISSN 1726-9687, Vienna, Austria

DOI: $10.2507 /$ daaam.scibook.2014.25 


\section{Introduction}

The issue of cutting on CNC milling machines and machining centers has recently proved to be a relatively dynamically developing area. Recent trends relate closely to the functional properties of machined surfaces as global competition creates strong economic pressure on manufacturing companies to produce their products with utmost efficiency. The production costs constitute approximately $40 \%$ of the engineering products prices and the machining technology represents about $30 \%$ of the labor intensity of industrial technologies, participating in the production.

Required surface quality of the work pieces is one of the important factors affecting not only the production technology but also production costs (Davim, 2010), and therefore designers must select the appropriate parameters considering the function of the proposed components. The high quality surface finish (of average arithmetic deviation of the profile $\mathrm{Ra}<0.8 \mu \mathrm{m}$ ) e.g. of molds, dies, turbine blades or other, is often unachievable without grinding (IT 5-6), thus making the whole production very time-consuming and costly (Tönshoff et al., 2001). Therefore the NC programmers already consistently use the numerous tools for optimization of the pathways on which the cutting tool moves during roughing, half-finishing or finishing milling. Due to special functions aiming e.g. at smoothing out the pathways (G64, spline interpolation, etc.), data compressors or working with the so-called forward regulation (elimination of lag error), successfully increase the fluency and precision of machining or eliminate the adverse effects of machine tool dynamics (Smith, 2008; Mickelson, 2007). This has enabled the milling centers to produce sufficiently precise technological features that were previously made by turning or drilling only (AB Sandvik Coromant, 2005).

Modelling of the milling process is the subject of many scientific studies (Kivanc \& Budak, 2004; Smith, Tlusty, 1991; Ávila \& Abramo, 2001). The focus of these studies nowadays is mainly on modelling of the suitable blade geometry for a particular application, on the prediction of the forces acting during the machining process, on the stability of the cutting process and the quality of the machined surface (Koenigsberger, Sabberwal, 1961; Kline et al., 1982; Budak \& Altintas, 1995; Altintas \& Engin, 2001). The results of the real milling are, however, influenced not only by the dynamic capabilities of the machining tools, cutting conditions or the wear of cutting tools, but also by the type of applied tools (their structure, macro and microgeometry etc.). Some deceleration in the process of cutting tools wear is achievable through optimization of the cutting conditions, a suitable coating technology (macro-geometric adjustment of the cutting tool, cleaning the tool before its coating and a the coating process itself, even the suitability of the chosen coating for a given application), as well as through the selection of ultra-fine-grained milling substrate (usually WC grains smaller than $0.8 \mu \mathrm{m}$ with Co content below $10 \%$ ) (Humar, 2008; Milling, 2007). Even such a modern cutting tool will still require a more accurate (better) positioning. The effect of deformation (deflection) of the cutting tool during operation, with respect to the high hardness and difficult 
machinability of the whole range of modern construction materials, the impact of the development of cutting tool wear during milling, the impact of changes in the power load of the cutting tool during machining, while bearing in mind the above-mentioned requirements for high quality surface finish, ensuring production efficiency, leads for instance to predictive positioning of the cutting tools to continuously controlled fiveaxis milling centers.

\section{Prediction of the amount of milling tools deformation}

Expert studies devote a great deal of attention to the power load prediction of cutting tools (Ávila \& Abramo, 2001). In publications dealing with the construction of cutting tools it is even possible to study analytical calculations aimed at the strength of different types of tools. This issue has been analysed by various authors, for example (Rasa, 1986), (Papez, 1980) and (Tlusty, 1999), while Tlusty focuses also on the influence of vibration during the cutting process. Kivanc \& Budak (2004) and (Budak \& Altintas, 1994) deals with end mill deformation during machining and formulates the analytical formulas for their calculations, including the derivation of transversal characteristics. A number of studies pay attention to the comparison and improvement of analytical solutions, MKP methods, even experimental tests. At the same time, it is necessary to take into account the wear of cutting blades and the associated change in the forces acting in the cutting process applied on the tool (workpiece) and its deformation. The research in the process of wear of cutting tools as well as measuring the power load is being conducted by authors (Lee et al., 1989) (Sarhan, 2001) and (Forejt \& Piska, 2006; Piska \& Polzer, 2003). The following analysis therefore pays attention to the deformation prediction of an end mill tool with a straight front at various force load (at different radial depth of cut $a_{e}$ ).

\subsection{Elastic deformation of end mills simplified models}

The study of elastic deformation of cutting tools simplified models (Fig. 1) allows to evaluate the importance of impact of the deflection size effect (equation 1 and 3 ) and of the cylindrical cutter torsion (equations 2 and 4 ) on the cutting process. The magnitude of this deformation is dependent not only on the dimensions of the tool (diameter, length), on its material properties (cemented carbides, high speed steels, etc.), but also on the size of the load forces. Tool deformation consists of composite stress energy complex, involving especially the bending, shear and torsion and their derivatives with respect to the applied force and torque in the form:

$$
\begin{aligned}
& y_{F}=\frac{\partial W}{\partial F}=\frac{1}{E} \cdot \int_{(l)}^{M_{y}(x)} \frac{\partial M_{y}(x)}{\partial F} \cdot d x+\frac{\beta}{6} \cdot \int_{(l)} \frac{T_{z}(x)}{G(x)} \cdot \frac{\partial T_{z}(x)}{\partial F} \cdot d x+\frac{1}{G} \cdot \int_{(l)} \frac{M_{k}(x)}{I_{p}(x)} \cdot \frac{\partial M_{k}(x)}{\partial F} \cdot d x, \\
& \varphi_{M}=\frac{\partial W}{\partial M}=\frac{1}{E} \cdot \int_{(l)}^{M_{y}(x)} \frac{\partial M_{y}(x)}{I_{y}(x)} \cdot d x+\frac{\beta}{6} \int_{(l)} \frac{T_{z}(x)}{G(x)} \cdot \frac{\partial T_{z}(x)}{\partial M} \cdot d x+\frac{1}{G} \cdot \int_{(l)}^{M_{k}(x)} \frac{\partial M_{k}(x)}{I_{p}(x)} \cdot d x
\end{aligned}
$$


where $W[\mathrm{~J}]$ is stress energy of the stressed sample, $F[\mathrm{~N}]$ is applied force, $E[\mathrm{~Pa}]$ is tensile modulus, $M_{y}(x)[\mathrm{N} . \mathrm{m}]$ is bending moment at point $x, I_{y}(x)\left[\mathrm{m}^{4}\right]$ is quadratic moment of inertia, $T_{z}(x)[\mathrm{N}]$ is shear force (cutting force), $G[\mathrm{~Pa}]$ is shear modulus, $M_{t}(x)[\mathrm{N} . \mathrm{m}]$ is torque and $I_{p}(x)\left[\mathrm{m}^{4}\right]$ is polar moment.

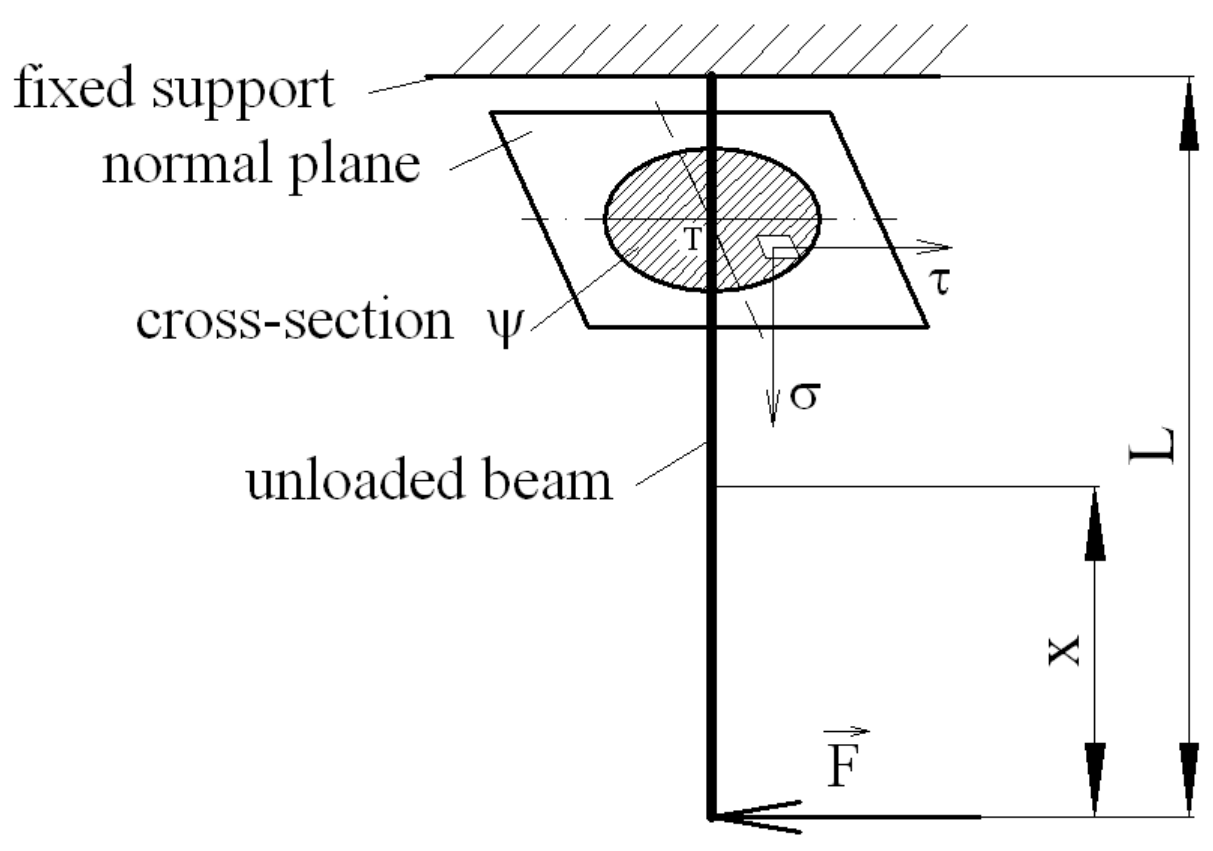

Fig. 1. Model of a clamped milling tool in the form of a cylindrical beam

Expression of the equations (1) and (2) after the mathematical transformation - Model of a clamped milling tool in the form of a cylindrical beam:

- deflection

$$
y(x)=\frac{F}{6 \cdot E \cdot I} \cdot\left(2 \cdot L^{3}-3 \cdot L^{2} \cdot x+x^{3}\right),
$$

- angle of rotation of the cross-section

$$
\varphi(x)=\frac{F}{2 \cdot E \cdot I} \cdot\left(L^{2}-x^{2}\right),
$$

where $F[\mathrm{~N}]$ is load force (also known as: $F_{c N}-$ refer to Fig. 1 or $F_{r}$-radial force), $E$ [MPa] is Young modulus (tensile modulus), $I\left[\mathrm{~m}^{4}\right]$ is quadratic moment of inertia, $L$ $[\mathrm{mm}]$ is analysed sample length, $x[\mathrm{~mm}]$ is distance from the applied force, $d[\mathrm{~mm}]$ is sample diameter.

Technical literature (Kivanc \& Budak, 2004; Budak, 2009) dealing with this issue presents a solution for the deflection of the cutting tool with two cross-sectional characteristics consisting of the following equation:

$$
w_{\text {max }}=\frac{F \cdot L_{1}^{3}}{3 \cdot E \cdot J_{1}}+\frac{1}{6} \cdot \frac{F \cdot L_{1} \cdot\left(L_{2}-L_{1}\right) \cdot\left(L_{2}+2 L_{1}\right)}{E \cdot J_{2}}+\frac{1}{6} \cdot \frac{F \cdot L_{2} \cdot\left(L_{2}-L_{1}\right) \cdot\left(2 L_{2}+L_{1}\right)}{E \cdot J_{2}},
$$


where the $L_{2}$ parameter characterizes the length of the beam (Fig. 2), which corresponds more to the commonly stated values in catalogues of end mill milling tools and the values programmed in CAM software.

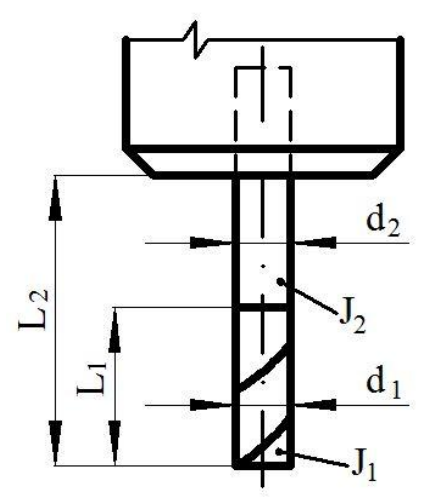

Fig. 2. Model of an end mill with two cross-cutting characteristics (Kivanc \& Budak, 2004)

Models with two cross-cutting characteristics, according to the professional literature (Kivanc \& Budak, 2004) or (Salgado, 2005), can be considered to be a sufficiently accurate prediction of the deformation caused by cutters deflection (deviation indicated less than $10 \%$ ). To simplify the deformation prediction of a relatively large number of types of milling tools that are on the market today and because of the complexity of measuring the characteristic dimensions of helical grooves and blades, it is possible to fill in specific constants into the deformation calculation. The calculation formula [24] then has the form:

$$
w=C \frac{F}{E}\left[\frac{L_{1}^{3}}{d_{1}^{4}}+\frac{\left(L_{2}^{3}-L_{1}^{3}\right)}{d_{2}^{4}}\right]^{N},
$$

where $C$ is a constant having a value of about $9.05,8.30$ or $7.93, N$ acquires a constant value of about $0.950,0.965$ and 0.974 for a four-, three-, or two-flutes monolithic cylindrical end mill (Kivanc \& Budak, 2004).

\subsection{Elastic Deformation of Detailed End Mills Models}

The above-mentioned models with two cross-cutting characteristics are also suitable for end mill tools, which have a different diameter of cutting and clamping sectors (the cutting portion may have a larger diameter than the diameter of the clamping part of the tool). The actual diameter of the cutting portion of the cutter is usually being replaced with an equivalent diameter that is smaller in value, and therefore better characterizes the attenuation of helical grooves cross-section. Such modified simplified models of cutters can be relatively easy to implement in the current engineering practice.

Considerably more complicated is to determine more accurate mathematical models for e.g. four-, three-, or two-flutes end mills. As can be seen from this picture, 
replacement of the milling tool diameter by a sole cylindrical beam of the same maximal diameter of the cutting portion suppresses numerous geometric variations of these cutter types (number of grooves, the core diameter, etc.).

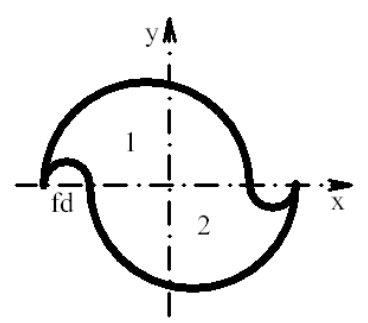

(a)

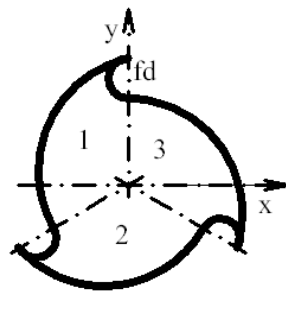

(b)

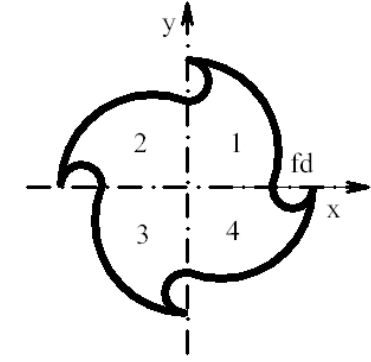

(c)

Fig. 3. Models of the sections of end mill tools with a straight front [24]:

(a) Double-flutes cutter, (b) Three-flutes cutter, (c) Four-flutes cutter

For more detailed consideration of the geometry of the blades and the grooves it is possible to split each one of these instruments into identical regions (Fig. 4), which can subsequently be characterized by mathematic equations (Kivanc \& Budak, 2004).

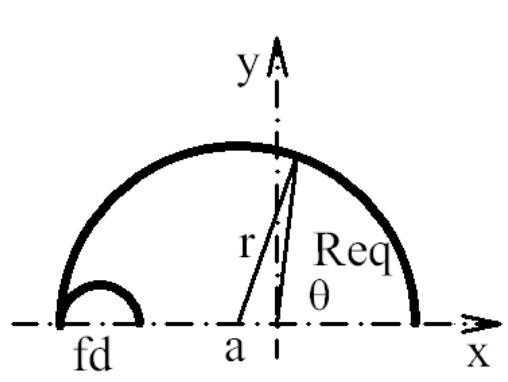

(a)

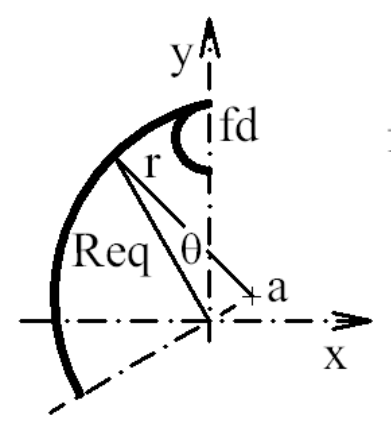

(b)

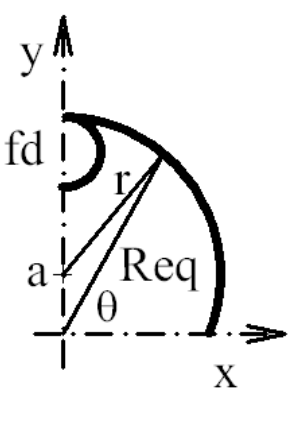

(c)

Fig. 4 Description of the cutter regions no. 1: (a) Double-flutes cutter, (b) Threeflutes cutter, (c) Four-flutes cutter

Mathematic description of the cutter regions (Fig. 4) [24]:

$$
R_{\text {eq2-flutes }}(\theta)=-a \cdot \cos (\theta)+\sqrt{\left(r^{2}-a^{2}\right)+a^{2} \cdot \cos ^{2}(\theta)},
$$

where $\theta$ takes values $0<\theta<\pi$,

$$
R_{\text {eq3-flutes }}(\theta)=a \cdot \cos \left(\theta+\frac{\pi}{3}\right)+\sqrt{\left(r^{2}-a^{2}\right)+a^{2} \cdot \cos ^{2}\left(\theta+\frac{\pi}{3}\right)},
$$

where $\theta$ takes values $0<\theta<2 \pi / 3$,

$$
R_{\text {eq4-flutes }}(\theta)=a \cdot \sin (\theta)+\sqrt{\left(r^{2}-a^{2}\right)+a^{2} \cdot \sin ^{2}(\theta)},
$$


where $\theta$ takes values $0<\theta<\pi / 2$.

The quadratic moment of the region no. 1 at the four-flutes [24] and double-flutes end mill model with a straight front can then be expressed as:

$$
\begin{gathered}
J_{x x 4-\text { flutes }}=\left[\int_{0}^{\frac{\pi}{2}} \int_{0}^{R_{\text {eq4-flutes }}(\theta)} \rho^{3} \cdot \sin ^{2}(\theta) d \rho d \theta\right]- \\
{\left[\frac{1}{8} \pi\left(\frac{f d}{2}\right)^{4}+\frac{\pi(f d / 2)^{2}}{2}\left(r+a-\frac{f d}{2}\right)^{2}\right],} \\
J_{y y 4-\text { flutes }}=\left[\int_{0}^{\pi / 2} \int_{0}^{R_{e q 4-f l u t e s}(\theta)} \rho^{3} \cdot \cos ^{2}(\theta) d \rho d \theta\right]-\left[\frac{1}{8} \pi\left(\frac{f d}{2}\right)^{4}\right], \\
I_{x x 2-f l u t e s}=\left[\int_{0}^{\pi} \int_{0}^{R_{e q 2}-f l u t e s(\theta)} \rho^{3} \cdot \sin ^{2}(\theta) d \rho d \theta\right]-\left[\frac{1}{8} \pi\left(\frac{f d}{2}\right)^{4}\right], \\
I_{y y 2-f l u t e s}=\left[\int_{0}^{\pi} \int_{0}^{R_{e q 2}-f l u t e s(\theta)} \rho^{3} \cdot \cos ^{2}(\theta) d \rho d \theta\right]- \\
{\left[\frac{1}{8} \pi\left(\frac{f d}{2}\right)^{4}+\frac{\pi(f d / 2)^{2}}{2}\left(r+a-\frac{f d}{2}\right)^{2}\right],}
\end{gathered}
$$

where $R_{e q}$ is the equivalent radius, $\rho$ the variable assuming values $0<\rho \leq R_{e q}(\theta), \vartheta$ the rotation of the position of the work piece center, $f d$ is a characteristic size of the tooth gap, $r$ is the radius of curvature of the dorsal surface of the flute relative to the position of point $a$, which defines the position of the region center.

After the transformation of the quadratic moment (moment of inertia) of the first region it is possible to calculate the total moment as:

$$
\begin{aligned}
& J_{x x 4-\text { flutes }, \text { whole }}=J_{y y 4-\text { flutes }, \text { whole }}=2 \cdot\left(J_{x x 4-\text { flutes }}+J_{y y 4-\text { flutes }}\right), \\
& J_{x x 3-\text { flutes }, \text { whole }}=J_{y y 3-\text { flutes }, \text { whole }}=1,5 .\left(J_{x x 4-\text { flutes }}+J_{y y 4-\text { flutes }}\right), \\
& J_{x x 2-\text { flutes }, \text { whole }}=2 .\left(J_{x x 2-\text { flutes }}\right), J_{y y 2-\text { flutes }, \text { whole }}=2 .\left(J_{y y 2-\text { flutes }}\right) .
\end{aligned}
$$

\section{Practical comparison of the accuracy of selected mathematical models}

The deflection of the cutting tool due to the radial component of the total applied force can be demonstrated e.g. during face-milling of a planar surface (Fig. 5). It can be even measured indirectly by using conventional equipment designed for a $2 \mathrm{D}$ or 3D structure analysis of machined surfaces. Results of experimentally machined flat surfaces using a four-flutes cutter, $6 \mathrm{~mm}$ in diameter, with a flat front are included in the first tab. 


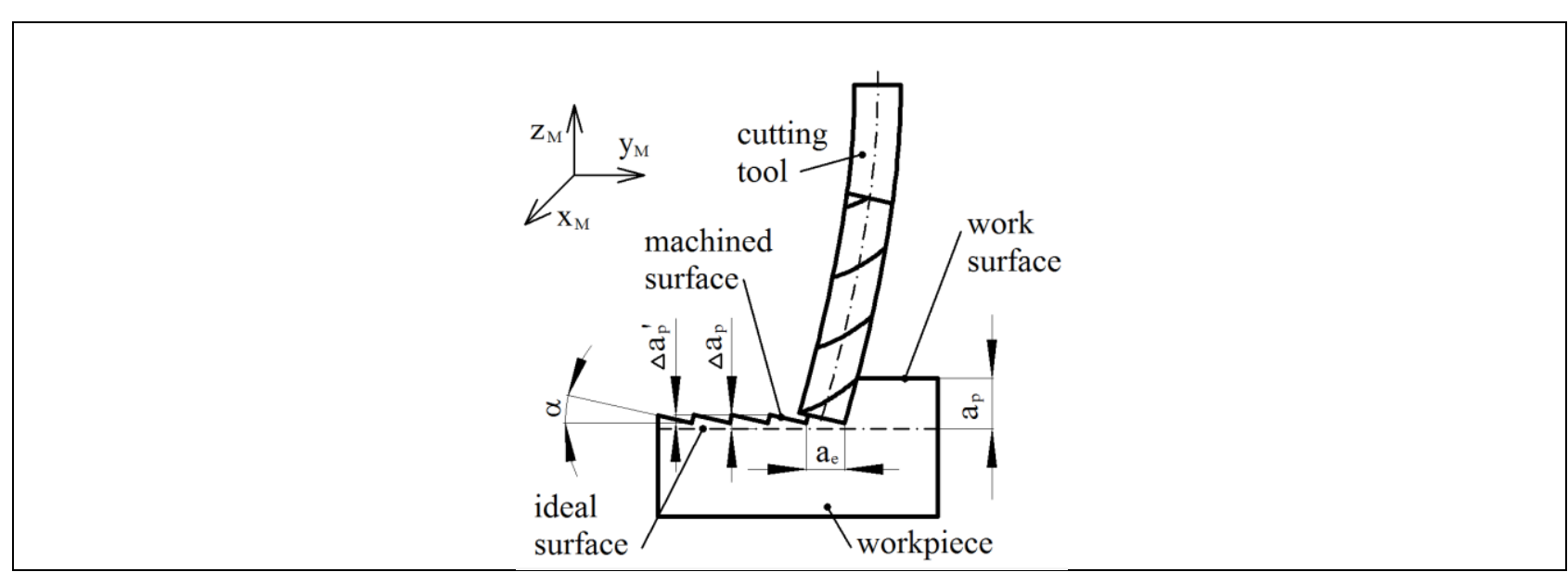

Fig. 5 Quality of a machined surface without the compensation of cutter deflection.

Key parameters of the experiment:

Milling machine: MCV1210/Sinumerik 840D pl,

Milling tool: type 06E4S50-16A06 SUMA, manufacturer Pramet Tools Ltd.,

Nominal cutting tool diameter: $\mathrm{d}=6 \mathrm{~mm}$ (equivalent diameter of the cutting portion $\mathrm{d}_{\mathrm{e}}=4 \mathrm{~mm}$ ),

Cutting tool length: $16 \mathrm{~mm}$ (length of grooves $\mathrm{L}_{1}=19 \mathrm{~mm}$ ),

Projection length of the cutter chucks: $\mathrm{L}=25 \mathrm{~mm}$,

No. of cutting tool flutes: $\mathrm{z}=4$,

Cutting tool material: SK $(\mathrm{E}=520 \mathrm{GPa})$,

Procedural liquid: Cimstar 597, $12 \%$ concentration,

Axial depth of cut: $a_{p}=3 \mathrm{~mm}$,

Machining direction: consecutive milling,

Moving speed: $\mathrm{v}_{\mathrm{f}}=2389 \mathrm{~mm} \cdot \mathrm{min}^{-1}$,

Cutting tool revs: $\mathrm{n}=13270 \mathrm{~min}^{-1}$,

Workpiece material: Silumin (12\% Si).

\begin{tabular}{|c|c|c|c|c|}
\hline \multirow[b]{2}{*}{$\begin{array}{c}\text { Radial depth } \\
\text { of cut ae } \\
\text { [mm] and } \\
\text { Radial force } \\
\text { Fr }_{\mathrm{r}}[\mathrm{N}]\end{array}$} & \multicolumn{3}{|c|}{$\begin{array}{l}\text { Predicted difference } \Delta \mathbf{a}_{p}{ }^{6} \text { caused by } \\
\text { cutters deflection }{ }^{*}[\mu \mathrm{m}]\end{array}$} & \multirow[b]{2}{*}{$\begin{array}{c}\text { Measured } \\
\text { difference } \Delta \mathrm{a}_{\mathrm{p}}{ }^{6} \\
\text { caused by cutters } \\
\text { deflection } \\
{[\mu \mathrm{m}]}\end{array}$} \\
\hline & $\begin{array}{c}\text { Cylindrical } \\
\text { beam } \\
(\mathrm{d}=6 \mathrm{~mm})\end{array}$ & $\begin{array}{c}\text { The cylindrical } \\
\text { beam with two } \\
\text { cross-sections }\left(\mathrm{d}_{\mathrm{e}}=\right. \\
4.0 \mathrm{~mm})\end{array}$ & $\begin{array}{l}\text { The cylindrical } \\
\text { beam with two } \\
\text { cross-sections } \\
\text { I4-flutes } \\
\left(d_{\mathrm{e}}=5.16 \mathrm{~mm}\right)\end{array}$ & \\
\hline $\begin{array}{c}a_{e}=1.5 \\
F_{r}=47.24\end{array}$ & 2.54 & 8.51 & 0.99 & 1.6 \\
\hline $\begin{array}{c}a_{e}=3 \\
F_{r}=92.71\end{array}$ & 4.99 & 16.71 & 3.88 & 4.0 \\
\hline $\begin{aligned} a_{e} & =5.7 \\
F_{r} & =149.17\end{aligned}$ & 8.03 & 26.88 & 11.87 & 14.17 \\
\hline
\end{tabular}

Tab. 1. The parameters of the machined surface due to cutters deformation - $\Delta a_{p}$. (without compensation; 2D analysis). 
Notice: Distance $\Delta a_{p}$ (Fig. 5) characterizes the maximal amount of the axial depth deviation of cut when machining without compensating cutters deflection. $\Delta a_{p}{ }^{\prime}$ is maximal roughness of the machined surface.

The results (Tab. 1) proved the mathematical model with the cylindrical beam with two cross-sections (blue highlighted values), to be the closest to real machining. However, these satisfactory results were achieved only by replacing the actual diameter of the active part of the cutting tool $\left(\mathrm{d}_{1}=6 \mathrm{~mm}\right.$, length of grooves $\mathrm{L}_{1}=19$ $\mathrm{mm}$ ) with an equivalent diameter $\mathrm{d}_{\mathrm{e}}=5.16 \mathrm{~mm}$ of the cutter cutting part.

Cutter deflection values predicted by the mathematical model incl. a cylindrical beam with two cross-sections while using the equivalent diameter of the cutter cutting part at the same time will be also used for predictive compensation of the cutter deformation for further processing of the identical planar surface. Tab. 2 sums up the values for setting the deflection compensation of the cutter for $\mathrm{NC}$ programming (using the direct positioning of the rotational axis A), and even for comparing the resulting value of the angle $\alpha$ and the difference $\Delta a_{p}{ }^{\prime}$ of the planar surface machined with the implemented compensation of the predicted deflection of milling tool.

\begin{tabular}{||c||c|c|c|c|c||}
\hline $\begin{array}{c}\text { Radial } \\
\text { depth of } \\
\text { cut } \\
\text { ae[mm] }\end{array}$ & $\begin{array}{c}\text { Set inclination } \\
\text { angle of cutter } \\
\alpha\left[^{\circ}\right] \text { for NC } \\
\text { programming }\end{array}$ & $\begin{array}{c}\text { Measured } \\
\text { angle of } \\
\text { inclination of } \\
\text { the machined } \\
\text { surface } \\
\alpha\left[^{\circ}{ }^{\circ}\right]\end{array}$ & $\begin{array}{c}\text { Cutter } \\
\text { deflection } \\
\text { reduced } \\
\text { approximately } \\
{[\%]}\end{array}$ & $\begin{array}{c}\text { Measured } \\
\text { difference } \\
\text { caused by } \\
\text { cutters } \\
\text { deflection } \\
\Delta \mathbf{a p}^{6}[\mu \mathrm{m}]\end{array}$ & $\begin{array}{c}\text { The } \\
\text { inaccuracy of } \\
\text { the machined } \\
\text { surface } \\
\text { reduced } \\
\text { approximately } \\
{[\%]}\end{array}$ \\
\hline $\begin{array}{c}\mathbf{1 . 5} \\
(\mathbf{0 . 2 5})\end{array}$ & $\begin{array}{c}0.03778^{\circ} \\
\left(0^{\circ} 2^{\circ} 16^{\circ}\right)\end{array}$ & $0.00935^{\circ}$ & $\mathbf{1 5 . 3 \%}$ & 0.248 & $\mathbf{1 5 . 5 \%}$ \\
\hline $\begin{array}{c}\mathbf{3} \\
(\mathbf{0 . 5 0 d})\end{array}$ & $\begin{array}{c}0.07417^{\circ} \\
\left(0^{\circ} 4^{\circ} 27^{\circ}\right)\end{array}$ & $0.03338^{\circ}$ & $\mathbf{4 3 . 7 \%}$ & 1.736 & $\mathbf{4 3 . 4 \%}$ \\
\hline $\begin{array}{c}\mathbf{5 . 7} \\
(\mathbf{0 . 9 5 d})\end{array}$ & $\begin{array}{c}0.11944 \\
\left(0^{\circ} 7^{\circ} 10^{\circ}\right)\end{array}$ & $0.07079^{\circ}$ & $\mathbf{4 9 . 7 \%}$ & 7.060 & $\mathbf{4 9 . 8 \%}$ \\
\hline
\end{tabular}

Tab. 2. Parameters of structure of the machined surface after the cutter deformation compensation (2D analysis).

Theoretical models predicting the deformation of the cutting tool by deflection then partly also allow the prediction of some structure parameters of the machined surface (waviness / inequality). However, this article mainly highlights and experimentally demonstrates that the effects of milling tool deflection is predictable and simultaneously partially reducible (Tab. 2), while using the same tools and cutting conditions.

The values in the Tab. 1 and 2 are calculated on the basis of the parameters measured by TalysurfIntra 50 device, which operates in contact 2D mode. A similar result was also observed using $3 \mathrm{D}$ digitalization of the machined surface by Alicona InfiniteFocus optical device (the device was lent by Intemac Solutions, Ltd. research center). Application of the mathematical model in combination with the progressive NC programming of linear paths, in this case extended by a constant value of the rotary axis A of a five-axis continuously controllable milling machine, led to a 
Polzer, A.; Piska, M. \& Dufkova, K.: On the Modern Cnc Milling With a Compens... reduction of inaccuracy of the machined surface of 50 to $85 \%$ (depending on the adjusted radial depth of cut).

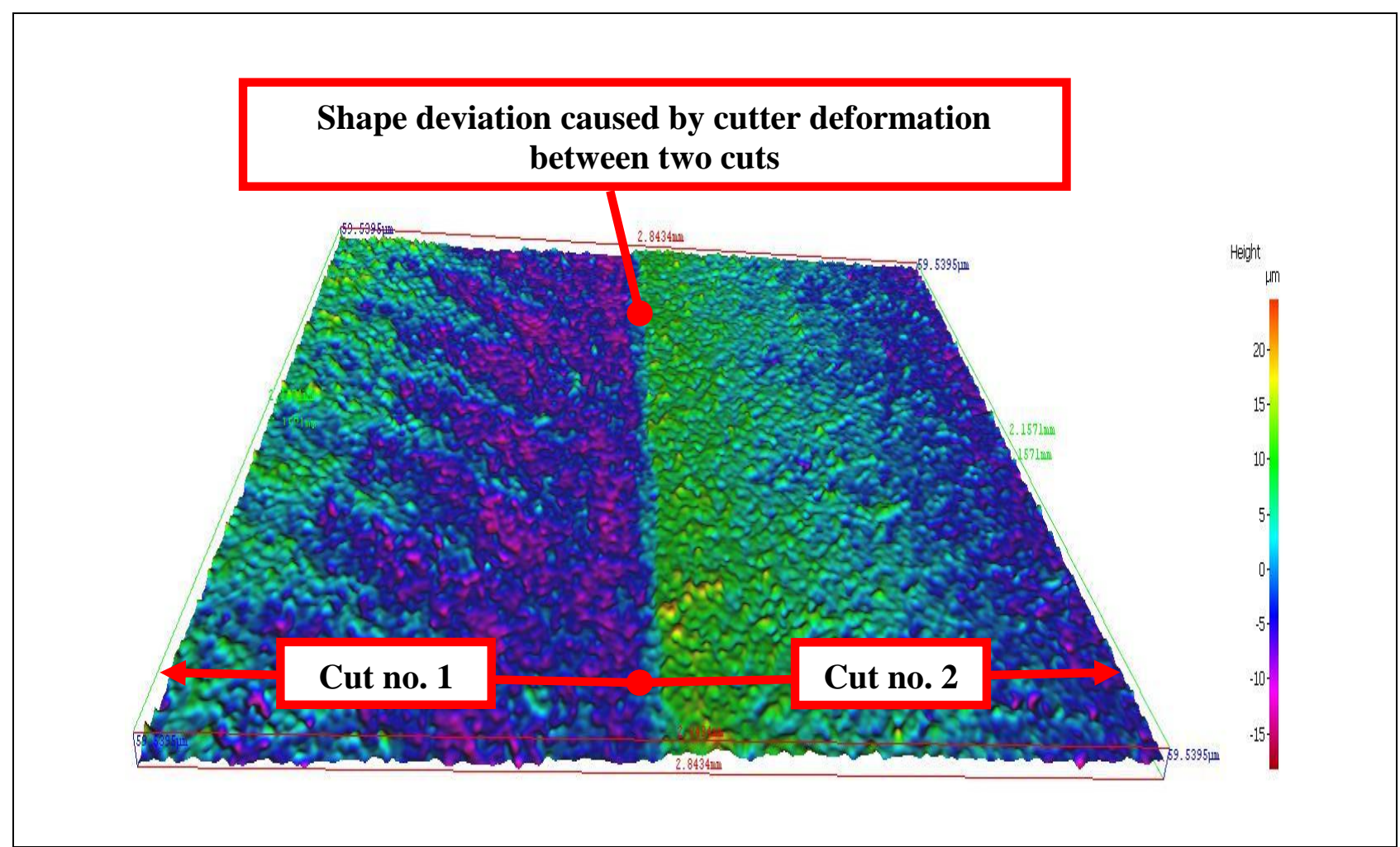

Fig. 6. Detail of the machined surface structure without cutter deflection compensation $\left(\mathrm{a}_{\mathrm{e}}=5.7 \mathrm{~mm}\right)$.

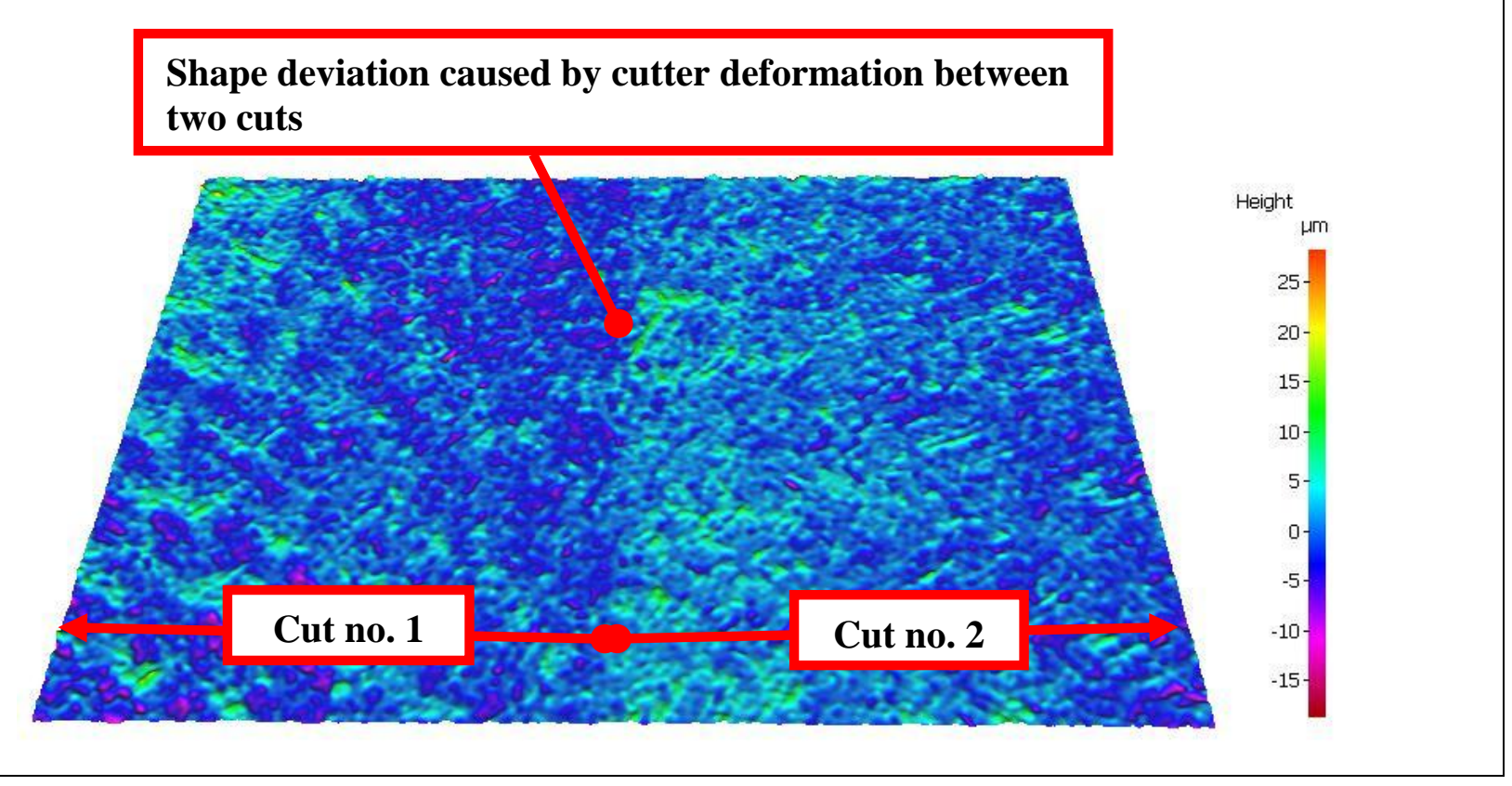

Fig. 7. Detail of the machined surface structure after cutter deflection compensation $\left(\mathrm{a}_{\mathrm{e}}=5.7 \mathrm{~mm}\right)$.

The final non-contact 3D scanning control of the machined surface structure $\left(\mathrm{a}_{\mathrm{e}}\right.$ $=0.95 \mathrm{~d}$ ) had also shown the reduction of the periodic inequalities to about $50 \%$ (Fig. 6 and 7). 


\section{Conclusions}

Deflection of the cutting tool is on machined surfaces evident. Some parameters of the machined surface structure are possibly predictable. Of the presented results it is evident that the closest to the real machining was the mathematical model with the cylindrical beam with two cross-sections with the simultaneous use of a reduced diameter of the cutting portion to an equivalent diameter of $5.16 \mathrm{~mm}$. This equivalent diameter is possible to calculate on basis of presented equations of the quadratic moment of inertia.

Application of the mathematical model in combination with the progressive NC programming of linear paths, in this case extended by a constant value of the rotary axis A of a five-axis continuously controllable milling machine, led to reduction of the machined surface inaccuracy of 50 to $85 \%$ (depending on the adjusted radial depth of cut).

The non-contact 3D scanning control of the machined surface structure had shown the reduction of the periodic inequalities to about $50 \%$.

Theoretical studies as well as practical experiments presented in this paper have shown that the influence of the deflection of the milling cutter is both predictable and reducible. In the next steps it will be appropriate to carry out measurements of cutting forces or engine power directly during milling. These deviations should be recalculated directly to the deflection of the cutting tool and in next elementary step (in the tact of interpolator) compensated.

\section{Acknowledgements}

The results of this project NETME CENTRE PLUS (LO1202) were obtained with the financial support of the Ministry of Education, Youth and Sports under the targeted support of the "National programme of sustainability I."

\section{References}

Davim,J.; (2010) Surface integrity in machining. London: Springer, 2010, 215 s. ISBN 978-1-84882-873-5

Tönshoff HK, Gey C, Rackow N. Flank milling optimization _ The flamingo project. Air \& Space Europe 2001; 3(3_4):60_3

Smith, Graham T. Cutting tool technology: industrial handbook. London: Springer, c2008, xii, 599 s. ISBN 978-1-84800-204-3

Mickelson, Dale. Guide to hard milling. New York: Industrial Press, 2007, xx, 228 s. ISBN 978-0-8311-3319-1

AB Sandvik Coromant. Technical manual of machinig: turning - milling drilling drilling - clamping of tools. [in czech]. 2005.10. Švédsko: Elanders, 2005

Kivanc, E. B., Budak, E. Structural modeling of end mills for form error and stability analysis. In International Journal of Machine Tools and Manufacture, Volume 44, Issue 11, September 2004. p. 1151-1161 
Polzer, A.; Piska, M. \& Dufkova, K.: On the Modern Cnc Milling With a Compens...

S. Smith, J. Tlusty. An overview of modeling and simulation of the milling proces. In Transactions of the ASME Journal of Engineering for Industry. 113 (1991). pp. 169175

Ávila R.F., Abramo, A.M. The effect of cutting fluids on the machining of hardened AISI 4340 steel. Journal of Materials Processing Technology. 2001, no.119, p. 21-26 F. Koenigsberger, A.J.P. Sabberwal. An investigation into the cutting force pulsations during milling operations. In International Journal of Machine Tool Design and Research. 1 (1961). pp. 15-33

W.A. Kline, R.E. DeVor, I.A. Shareef. The prediction of surface accuracy in end milling. In Transactions of the ASME Journal of Engineering for Industry. 104 (1982). pp. 272-278

E. Budak, Y. Altintas. Modeling and avoidance of static deformations in peripheral milling of plates. In International Journal of Machine Tools and Manufacture. 34 (3) (1995). pp. 459-476

Y. Altintas, S. Engin. Generalized modeling of mechanics and dynamics of milling cutters. In Annals of the CIRP. 50 (2001). pp. 25-30

Y. Altintas, E. Budak. Analytical prediction of stability lobes in milling. In Annals of the CIRP. 44 (1995). pp. 357-362

Humar, Anton. Materials for cutting tools. [in czech]. Praha: MM publishing, 2008, 235 s. ISBN 978-80-254-2250-2

Milling: professional conference. [in czech]. Brno: VUT Fakulta strojního inženýrství, 2007, 205 s. ISBN 80-214-3239-X

Rasa, J. Computational methods in the design of cutting tools. [in czech]. SNTL/ALFA Praha, 1986, $460 \mathrm{~s}$

Papez, K. The construcion of the tools. [in czech]. I. 2. vyd. Brno: SNTL, 1980, $376 \mathrm{~s}$ Tlusty, J. Manufacturing Process and Equipment. 1st edition. Prentice Hall, 1999. 928 p. ISBN-10: 0201498650

Budak, E, Altintas, Y. Peripheral milling conditions for improved dimensional accuracy. Int. J. Mach. Tools Manuf, Vol. 34, no. 7, pp. 907-918. Oct. 1994

Lee, L.C., Lee, K.S., Gan, C.S. On the correlation between dynamic cutting force and tool wear, Int. J. Mach. Tools Manuf.Vol. 29, No.3, 1989, p. 295-303

Sarhan, A. at al. Interrelationships between cutting force variation and tool wear in end- milling. In Journal of Materials Processing Technology. Volume 109, Issue 3, 15 February 2001. p. 229-235

Forejt, Milan a Miroslav PISKA. Theory of machining, forming and tools. [in czech]. 1. vyd. Brno: Akademické nakladatelství CERM, 2006, 225 s. ISBN 80-214-2374-9

PISKA, M., POLZER, A. The study of roughing mills cutting produced by ZPS-FN, Plc., Zlin. [in czech]. In Sborník odborné konference Frézování III. Brno: FSI VUT v Brně, 2003. s. 145-158. ISBN 80-214-2436-2

Budak, Erhan. Machining dynamics: fundamentals, applications and practices. London: Springer, c2009, xviii, 328 s. Springer series in advanced manufacturing. ISBN 978-1-84628-367-3

Salgado M, A. aj. Evaluation of the stiffness chain on the deflection of end-mills under cutting forces. In International Journal of Machine Tools and Manufacture, Vol. 45, I. 6, 2005. p. 727-730 